\title{
Behandling av akutt hjerteinfarkt i distriktene
}

\author{
Transport til invasivt senter for $\mathrm{PCl}$-behandling umiddelbart etter \\ trombolyse synes fordelaktig i distriktene ved akutt ST-elevasjons- \\ hjerteinfarkt.
}

ST-elevasjonshjerteinfarkt bør behandles med perkutan koronar intervensjon (PCI) dersom behandlingen kan gis innen 90-120 minutter. I områder med lange avstander til invasivt senter er trombolytisk behandling primær behandling. Optimal behandling etter trombolyse er imidlertid ikke avklart. Noen studier har vist gunstig effekt av tilleggsbehandling med koronarangiografi og PCI. Ingen av disse studiene har inkludert pasienter med lang transportvei til invasivt senter.

Nå foreligger resultatene fra en klinisk, randomisert studie på pasienter med akutt ST-elevasjonshjerteinfarkt med lang vei til invasivt senter (1). Studien omfattet pasienter i Hedmark og Oppland med $100-400 \mathrm{~km}$ reisevei til nærmeste PCIsenter. Etter trombolytisk behandling ble 266 pasienter randomisert til umiddelbar transport til Ullevål universitetssykehus for angiografi og PCI eller til en konservativ strategi som innebar innleggelse i lokalsykehus med rask transport til Ullevål ved tegn til mislykket trombolysebehandling.

- Primært endepunkt var sammensatt av død, reinfarkt, slag eller nye iskemiske hendelser innen 12 måneder. Det var lavere forekomst av dette endepunktet i tidlig invasiv gruppe enn i konservativ gruppe, henholdsvis $21 \%$ mot $27 \%$, men forskjellen var ikke statistisk signifikant, sier prosjektleder Sigrun Halvorsen ved Hjertemedisinsk avdeling, Oslo universitetssykehus, Ullevål.

- Det sekundære endepunktet var død, reinfarkt eller slag. Dette viste seg å være signifikant i favør av tidlig invasiv utredning, med henholdsvis $6 \%$ og $16 \%$.
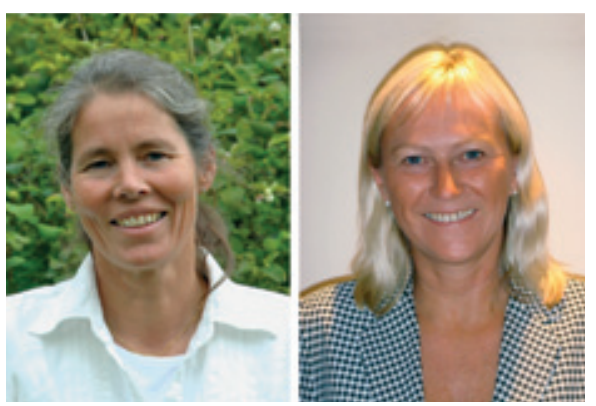

Ellen Bøhmer (til venstre) (foto privat) og Sigrun Halvorsen (foto Håkon H. Hortemo)

Til tross for intens antitrombotisk medikasjon var det få blødninger, uten forskjell mellom gruppene. Det var få alvorlige hendelser under transport: én død og fire med ventrikkelflimmer som ble vellykket defibrillert. Det var ingen forskjell mellom gruppene i infarktstørrelse.

Resultatene viser at tidlig invasiv behandling etter trombolyse synes fordelaktig også ved lange transporter. Dette vil ha betydning for hvordan vi i fremtiden behandler ST-elevasjonsinfarkter der det er lang vei til invasivt senter, sier Halvorsen.

\section{Erlend Hem}

erlend.hem@medisin.uio.no

Tidsskriftet

\section{Litteratur}

1. Bøhmer E, Hoffmann P, Abdelnoor M et al. Efficacy and safety of immediate angioplasty versus ischemia-guided management after thrombolysis in acute myocardial infarction in areas with very long transfers. J Am Coll Cardiol 2009; doi:10.1016/ j.jacc.2009.08.007.

\section{Ordforklaringer}

NORDISTEMI: NORwegian study on Dlstrict treatment of ST-Elevation Myocardial Infarction. Undersøkelsen ble gjennomført som et samarbeidsprosjekt mellom lokalsykehusene i Sykehuset Innlandet, ambulansetjenesten og Ullevål universitetssykehus. Lokalsykehusene rekrutterte pasientene og var også ansvarlig for mye av oppfølgingen, mens Ullevål universitetssykehus var hovedsete for studien og senter for den invasive behandlingen.

\section{Er du i ferd med å publisere eller har du nylig publisert i et internasjonalt tidsskrift? Send tips til erlend.hem@medisin.uio.no}

www.tidsskriftet.no/norskforskning

\section{Klinisk hjerteforskning}

\section{Artikkelen er skrevet av fem norske forskere.}

Artikkelens førsteforfatter er overlege Ellen Bøhmer ved Sykehuset Innlandet Lillehammer. Hun har vært stipendiat på prosjektet og har koordinert studien i distriktene. Hennes veileder er seksjonsoverlege Sigrun Halvorsen ved Hjertemedisinsk avdeling, Oslo universitetssykehus, Ullevål, som også har vært prosjektleder for studien. Artikkelforfatterne er Ellen Bøhmer, Pavel Hoffmann, Michael Abdelnoor, Harald Arnesen og Sigrun Halvorsen.
Artikkelen ble e-publisert 9.9.2009i Journal of the American College of Cardiology (http:// content.onlinejacc.orgl, som er et av de høyest rangerte kardiologiske tidsskriftene 